\title{
Adsorption of Orange-G dye by the dried powdered biomass of Chlorella vulgaris Beijerinck
}

\author{
Sunil Kumar ${ }^{1, *}$, Amrik Singh Ahluwalia ${ }^{1}$ and Mayank Uday Charaya ${ }^{2}$ \\ ${ }^{1}$ Department of Botany, Panjab University, Chandigarh 160 014, India \\ ${ }^{2}$ Department of Botany, CCSU, Meerut 250 004, India
}

Decolourization potential of microalgal biomass of an unicellular green alga (Chlorella vulgaris) was studied using different concentrations of Orange-G dye. Several parameters were also optimized for better removal of the tested dye from its aqueous solution. Langmuir and Freundlich models were tested for equilibrium studies and experimental data of the present study are better explained by the Freundlich model. FTIR data showed that five functional groups were probably involved in the adsorption of the dye. The biosorption process using algae (including $C$. vulgaris) offers an excellent biosystem for the remediation of final discharge of textile effluents.

Keywords: Adsorption, Chlorella vulgaris, dyes, infrared spectrum.

WATER resources play a central role in human development, and quality of water supports the sustainable development of various communities and ensures healthy human life ${ }^{1}$. Rapid growth and development of human beings in the form of rapid industrialization, urbanization and other anthropogenic activities are the main causes for change in water quality of freshwater bodies, which make it unsuitable for human consumption and aquatic life ${ }^{2}$. Synthetic colouring agents are among the major threats for polluting aquatic resources. The use of dyes and pigments has increased due to rapid industrialization and man's desire for colour ${ }^{3}$. Several industries like textiles, food, cosmetics, paper, leather, pharmaceutical, colour photography, food, etc. widely use synthetic dyes because they are cost-effective in production, have variety and firmness in colour $^{3,4}$. Approximately, 10,000 types of synthetic colouring products have been used by different textile industries. It is estimated that more than $7 \times 10^{5}$ tonnes of dyes is produced worldwide annually and $10-15 \%$ of the dyes are released during the process of colouration and manufacturing $^{5-7}$. Thus a huge volume of coloured wastewater is discharged and received by aquatic bodies every year ${ }^{8}$. Origin of most of the dyes is synthetic

*For correspondence. (e-mail: sunilkumarbotany@gmail.com) and they have a complex atomic structure that is highly durable and resistant to biological degradation ${ }^{9}$. The presence of dyes in aquatic resources in low concentration $(1 \mathrm{ppm})$ changes the properties like transparency of water, phosynthetic activity of phytoplankton and solubility of gas in aquatic bodies. However, $300 \mathrm{ppm}$ is the average concentration reported in coloured wastewater from textile manufacturing processes ${ }^{10,11}$. Coloured water discharged from different industries into aquatic bodies reduces the penetration of light inside and directly affects the process of photosynthesis ${ }^{12}$. The adverse effect on human health includes dermatitis, allergy, skin irritation ${ }^{13}$ and mutation which may cause cancer ${ }^{14,15}$. The technology used for the treatment of coloured wastewater includes flocculation, ozonization, adsorption and precipitation, but these are not cost-effective, are relatively inefficient and not adaptable to different types of coloured wastewaters ${ }^{16}$. Biosorption is a new technology which has received great attention as a cheap, clean and efficient method for wastewater treatment ${ }^{17,18}$. It involves the use of biomass of photosynthetic aquatic organisms, such as algae, aquatic plants or moss (bryophytes), and represents readily available sorbents for the removal of contaminants from wastewater or polluted water systems $^{19}$. It is well known that algae contain proteins, polysaccharides and lipids ${ }^{20}$. These play an important role in the process of biosorption due to the presence of different functional groups, such as hydroxyl, carboxylate, phosphate, sulphate and amino groups. Studies have been done earlier regarding microalgal role in the adsorption of dyes and heavy metals from polluted water $^{21-23}$. In this study we explore the application of Chlorella vulgaris, a grass green alga, in bioremediation of dye effluents.

\section{Materials and methods \\ Basic characteristics and molecular structure of Orange-G dye}

In the present study, an orange crystalline powder synthetic azo dye (Orange-G, HiMedia) was used for 
Table 1. Basic characteristics of Orange-G dye

\begin{tabular}{lccccc}
\hline Physical appearance & CAS no. & CI no. & Molecular weight (g mol $\left.{ }^{-1}\right)$ & Formula & $\lambda_{\max (\mathrm{nm})}$ \\
\hline Orange crystalline powder (HiMedia) & $1936-15-8$ & 16230 & 452.37 & $\mathrm{C}_{16} \mathrm{H}_{10} \mathrm{~N}_{2} \mathrm{Na}_{2} \mathrm{O}_{7} \mathrm{~S}_{2}$ & 478 \\
\hline
\end{tabular}

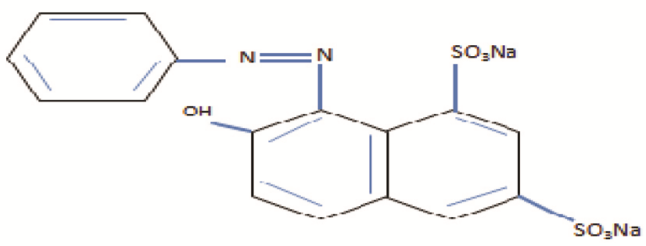

Figure 1. Molecular structure of Orange-G dye.

biosorption experiments. The basic characteristics and molecular formula of the test dye are given in Table 1 and Figure 1 respectively.

\section{Determination of maximum absorption $\left(\lambda_{\max }\right)$ of the dye}

A solution of $10 \mathrm{ppm}$ dye concentration was prepared and $\mathrm{pH}$ adjusted to 7 . The optical density was measured at $400-800 \mathrm{~nm}$ and maximum optical density $\left(\lambda_{\max }\right)$ observed at $478 \mathrm{~nm}$ (Figure 2).

\section{Preparation of test dye solutions}

Orange-G stock solution was prepared by dissolving weighed dose of test dye in distilled water. Working solutions of different concentrations (5-40 ppm) were prepared by dilution of stock solution.

\section{Culture and harvesting of algal species}

The alga used in the decolourization experiment was isolated from a freshwater pond and identified as Chlorella vulgaris (Figure 3 ) with the help of compound microscopy using standard monograph ${ }^{24}$. C. vulgaris was grown in Hafkin flasks using BG-11 growth medium ${ }^{25}$. Growth conditions comprised light intensity $1800 \pm 100$ lux, temperature $24^{\circ} \pm 2^{\circ} \mathrm{C}, 14: 10 \mathrm{~h}$ light and dark period and $\mathrm{pH}$ 7.4 using dilute $\mathrm{NaOH}$ and $\mathrm{HCl}$. Algal biomass was harvested via flocculation using saturated solution of potash alum. The harvested biomass was washed thrice using tap water and dried at $50^{\circ} \mathrm{C}$ in an hot-air oven. After drying, the biomass was crushed with the help of mortar and pestle and then sieved ( $85 \mu \mathrm{m}$ pore size) to obtain uniform-sized particles.

\section{Decolourization experiment}

Batch mode of experiments were performed to optimize different parameters effecting the decolourizing reaction.
Experimental conditions included $100 \mathrm{ml}$ Erlenmeyer flasks of Borosil-make containing $50 \mathrm{ml}$ solution of test dye on a rotatory shaker at $130 \pm 5 \mathrm{rpm}$ for $10 \mathrm{~min}$ at room temperature under neutral $\mathrm{pH}$. Decolourization experiment was conducted using one factor at a time and rest of the factors was kept constant. Optimization of the affecting factors for maximum adsorption efficiency of algal biomass decolourization, experiments were conducted at various dye concentrations (5-40 ppm), microalgal biomass dosage $(25-200 \mathrm{mg})$, reaction time (10$160 \mathrm{~min})$, temperature $\left(10-50^{\circ} \mathrm{C}\right)$ and $\mathrm{pH}(5-9)$. After adsorption reaction, all the samples were filtered through $3 \mu \mathrm{m}$ filter paper (HiMedia 237). Concentration of dye in the filtrate was calculated using a Systronics Double Beam Spectrophotometer-2202 at the absorption maxima wavelength of $478 \mathrm{~nm}$. The decolourization percentage $(R \%)$ was determined using the formula

$$
\left[\left(C_{i}-C_{f}\right) / C_{i}\right] \times 100
$$

where $C_{i}$ is the initial concentration of test dye (ppm) and $C_{f}$ the concentration of dye filtrate (ppm) after adsorption reaction. The specific dye uptake by the algal biomass was determined as

$$
Q=V\left(C_{i}-C_{f}\right) / \mathrm{m}
$$

where $Q$ is the dye absorption ( $\mathrm{ml}$ of dye/mg absorbent); $V$ the working sample volume $(\mathrm{ml}) ; C_{i}$ the initial dye concentration of working sample $(\mathrm{mg} / \mathrm{l}) ; C_{f}$ the final dye concentration of working sample after adsorption reaction $(\mathrm{mg} / \mathrm{l})$ and $m$ is the dose of dried adsorbent (mg).

\section{Adsorption isotherms}

Empirical models, viz. Freundlich ${ }^{26}$ and Langmuir ${ }^{27}$ were employed for single-solute adsorption system, while for multiple conditions modified Langmuir model was used for biosorption equilibria of the test alga.

Freundlich equation: $q_{e}=K_{\mathrm{F}} C_{e}^{1 / n}$,

Langmuir equation: $q_{e}=\frac{q_{\max } K_{\mathrm{L}} G_{e}}{1+K_{\mathrm{L}} C_{e}}$,

where $q_{\mathrm{e}}$ is amount of dye adsorbed by unit weight of adsorbent when reactions reached the stage of equilibrium $(\mathrm{mg} / \mathrm{g}) ; q_{\max }$ the maximal dose of test dye adsorbed by 


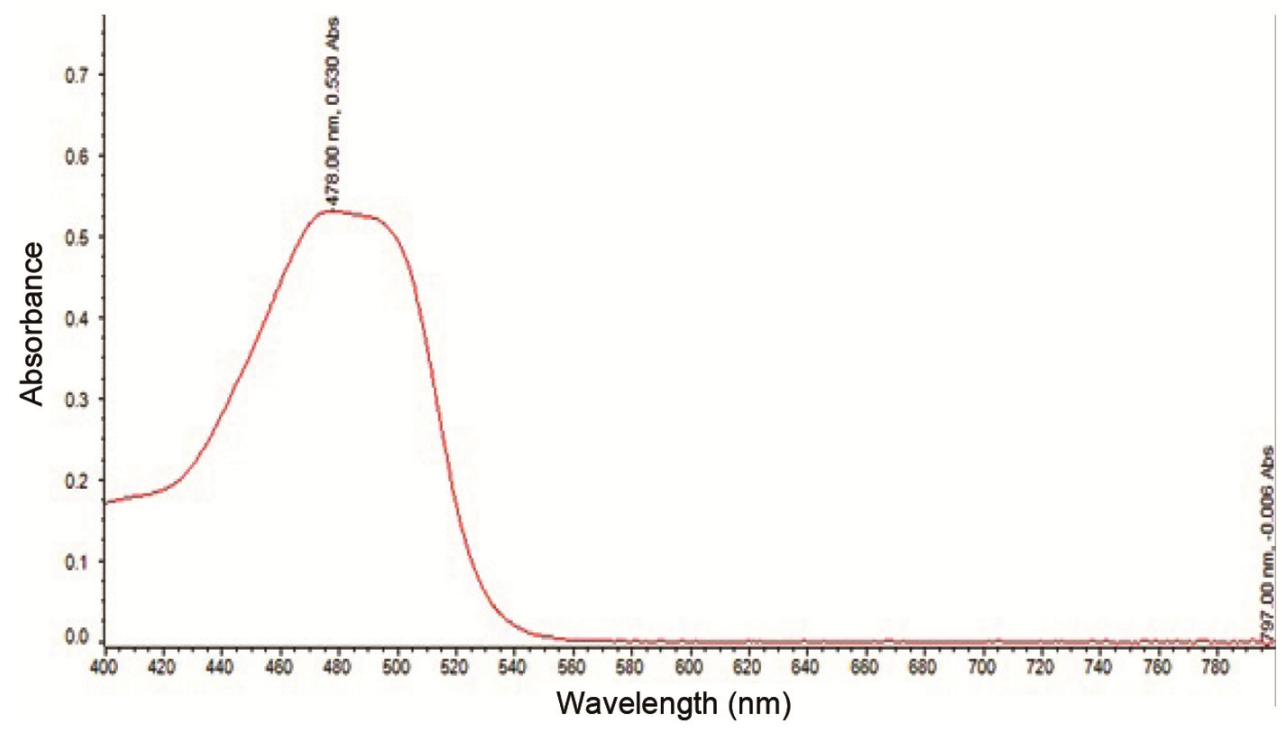

Figure 2. Determination of $\lambda_{\max }$ by Systronics -2202 double beam spectrophotometer.

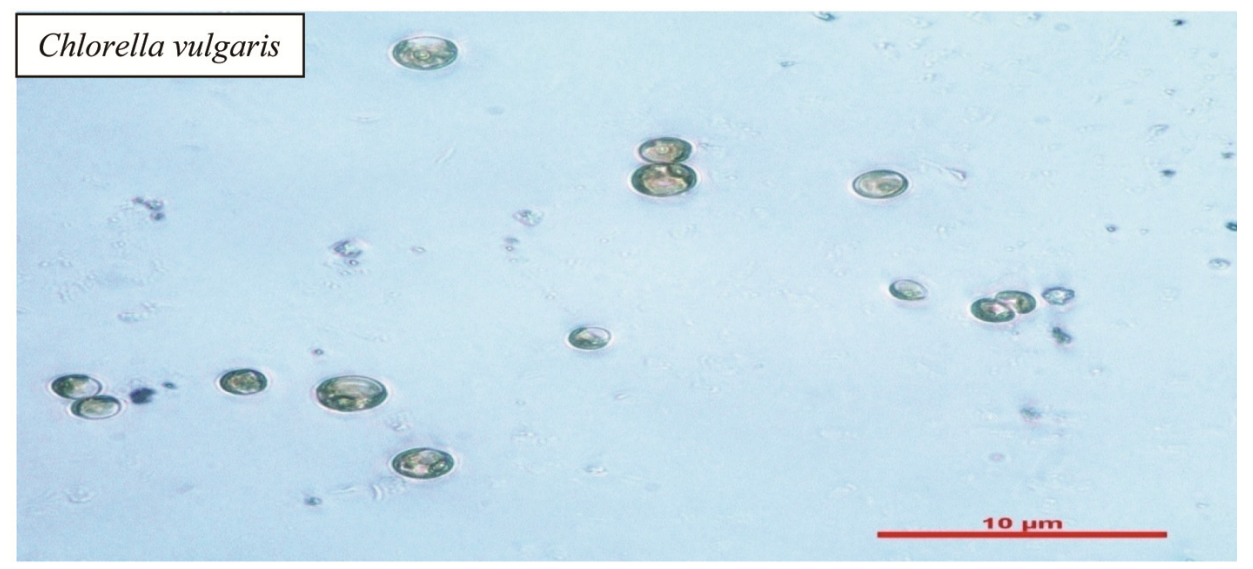

Figure 3. Microscopic image of the test alga.

unit weight of adsorbent $(\mathrm{mg} / \mathrm{g}) ; K_{\mathrm{L}}$ the Langmuir constant of adsorption reaction which characterizes affinity of binding sites for the test dye, present on the surface adsorbent $(1 / \mathrm{mg}) ; C_{\mathrm{e}}$ the residual concentration of test dye $(\mathrm{mg} / \mathrm{l})$ at equilibrium; $K_{\mathrm{F}}$ the constant of Freundlich adsorption reaction which represents the magnitude of adsorption reaction $(\mathrm{mg} / \mathrm{g})$ and $1 / n$ is the heterogeneity factor representing adsorption intensity.

\section{Characterization of algal biomass}

Functional groups present on the algal biomass and changes in them after adsorption of dye were studied using FTIR spectroscopy. The algal biomass was mixed in potassium bromide salt (FTIR-grade) and the pellet was analysed for IR spectrum (range of IR analysis 400$4000 \mathrm{~cm}^{-1}$ ) to identify the functional groups.

\section{Results and discussion}

Azo dyes are carcinogenic, mutagenic, toxic as well as hazardous to human health ${ }^{28}$. Discharge of coloured wastewater affects water transparency, aquatic photosynthesis, gas solubility and aesthetics of water bodies; it is toxic to aquatic ecosystem and ultimately results in serious environmental complications worldwide ${ }^{29}$. Wastewater from textile industries is characterized by high salinity, strong colour, variable $\mathrm{pH}$, high temperature and high COD (chemical oxygen demand) ${ }^{30}$. Microalgae play a central role in the fixation of $\mathrm{CO}_{2}$, which makes them a good candidate for bioremediation of coloured wastewater $^{31}$. Microalgae in both viable and non-viable forms have been reported in the process of colour removal from wastewater. The procedures associated with removal of dyes include biosorption and bioconversion ${ }^{32}$. Microalgae such as Chlorella were chosen due to their ability to grow 
best in wastewater and attain maximum rate of decolourization from textile wastewater ${ }^{32-34}$.

\section{Effect of initial dye concentration}

Experiments were performed to study the effect of initial dye concentration $(5-40 \mathrm{ppm})$ on the adsorption process. The results showed maximum sorption (38\%) at $5 \mathrm{ppm}$. A continuous reduction in adsorption was observed with increase in dye concentration. This clearly shows that dye adsorption depends on concentration of the solution. A dye concentration of $5 \mathrm{ppm}$ was selected for subsequent experiments (Figure 4).

\section{Effect of biomass dosage}

The results for dye adsorption by different biomass dosages showed that adsorption does not follow a regular pattern. Adsorption initially increased up to $38 \%$ and later decreased. Maximal decolourization was observed to be $38 \%$ with $50 \mathrm{mg}$ biomass dosage. Higher dose ( $>50 \mathrm{mg}$ ) showed almost same percentage of adsorption. Therefore, a biomass dosage of $50 \mathrm{mg}$ was selected for the next experiment (Figure 5).

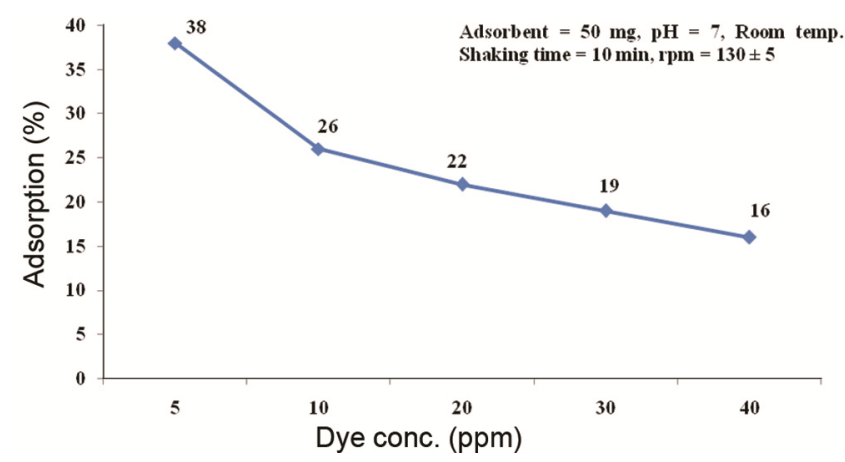

Figure 4. Per cent adsorption of Orange- $\mathrm{G}$ from its aqueous solutions of different concentrations.

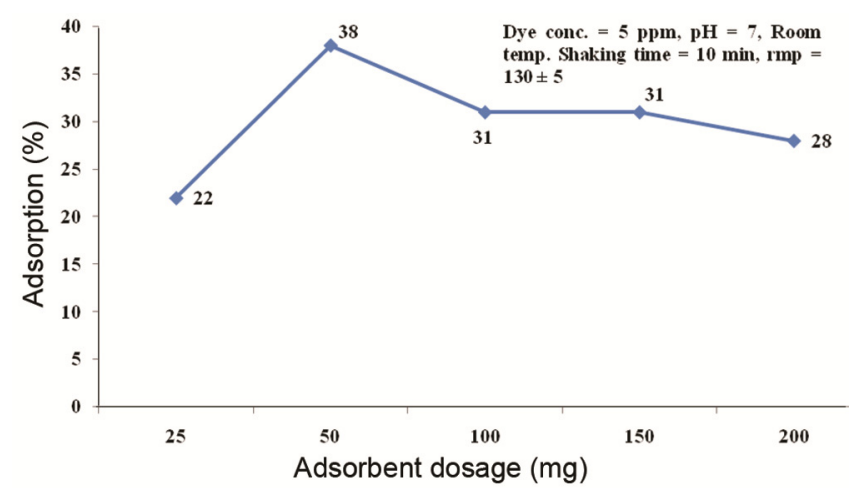

Figure 5. Per cent adsorption of Orange-G by different biomass dosages.

\section{Effect of time}

Variation in the magnitude of decolourization was observed with change in time of adsorption reaction. Maximum adsorption observed was $37 \%$ within $10 \mathrm{~min}$ of reaction time. After $10 \mathrm{~min}$, there was no significant change in adsorption up to $160 \mathrm{~min}$ of reaction time. Hence optimum time period of $10 \mathrm{~min}$ was selected for the next experiment (Figure 6).

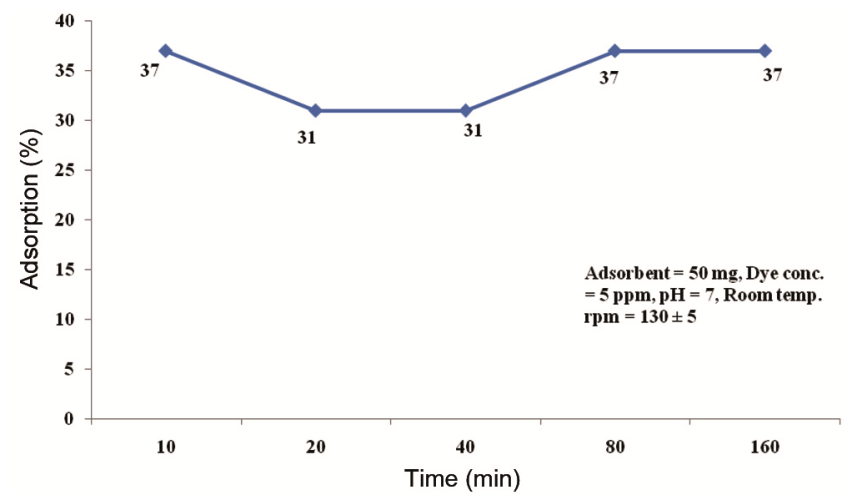

Figure 6. Per cent adsorption of Orange-G after different time intervals.

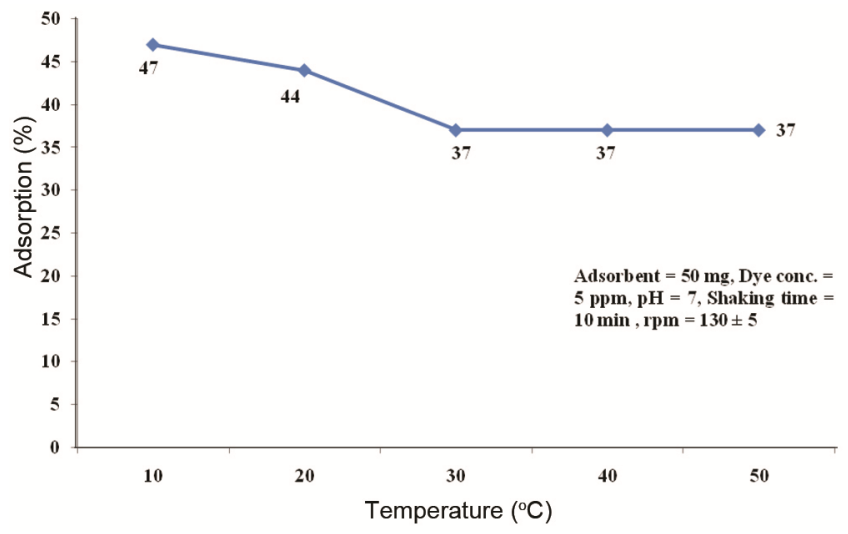

Figure 7. Per cent adsorption of Orange-G at different temperature regimes.

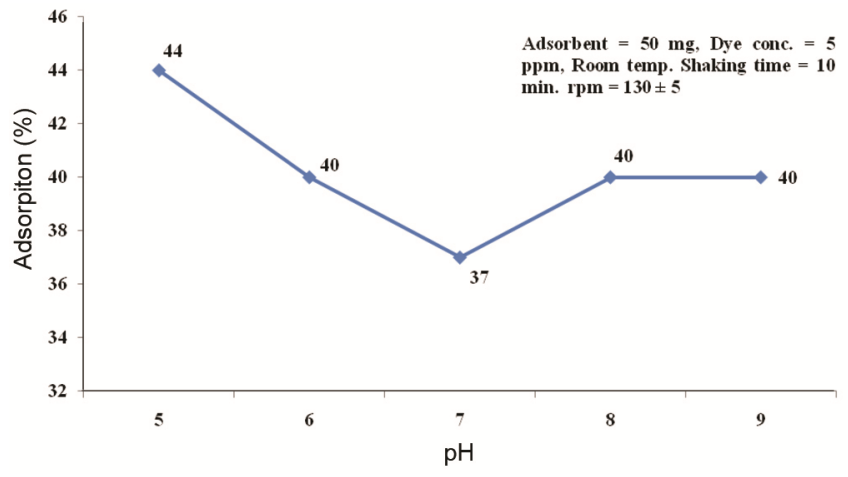

Figure 8. Per cent adsorption of Orange-G at different $\mathrm{pH}$ values. 


\section{RESEARCH ARTICLES}

Table 2. Freundlich and Langmuir isotherm constants of adsorption reaction of Orange-G by Chlorella species for different variables

\begin{tabular}{|c|c|c|c|c|c|c|c|c|}
\hline \multirow[b]{2}{*}{ Parameters } & \multicolumn{4}{|c|}{ Freundlich isotherm constants } & \multicolumn{4}{|c|}{ Langmuir isotherm constants } \\
\hline & $N$ & $1 / n$ & $k_{\mathrm{f}}$ & $R^{2}$ & $A$ & $B$ & $1 / a b$ & $R^{2}$ \\
\hline Dye concentration & 0.324 & 3.082 & 22.286 & 0.986 & 0.402 & 1.25 & 1.990 & 0.799 \\
\hline Adsorbent dosage & 2.415 & 0.414 & 4.100 & 0.980 & 0.163 & 0.714 & 8.592 & 0.925 \\
\hline Time & 1.945 & 0.514 & 4.318 & 1.0 & 0.263 & 0.540 & 7.041 & 1.0 \\
\hline
\end{tabular}

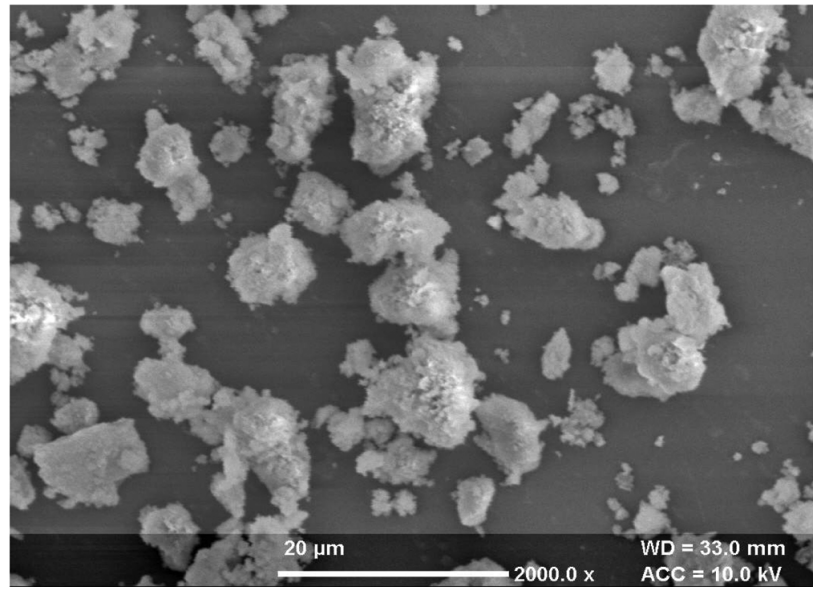

Figure 9. SEM image of unloaded biomass particles.

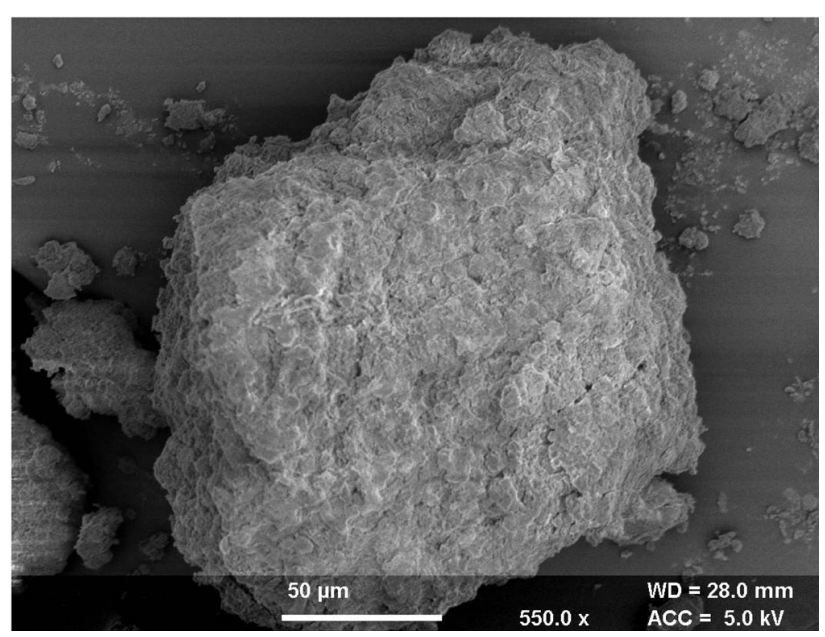

Figure 10. SEM image of algal biomass particles loaded with the dye.

\section{Effect of temperature}

It was observed that maximum adsorption was at $10^{\circ} \mathrm{C}$ and it decreased thereafter with increase in temperature. Thus, there is thermal deactivation of the dye-binding sites. It involves extra resources to maintain low temperatures at industrial level for the treatment of coloured wastewater and this results in increased cost of the treatment process. Therefore, the experiment was conducted at room temperature (Figure 7).

\section{Effect of $p H$}

The adsorption process was significantly affected by initial $\mathrm{pH}$ of solution, because $\mathrm{pH}$ changes the ionization of test dye and binding sites of the adsorbent. The results revealed that the range of acidic $\mathrm{pH}(5-7)$ showed more adsorption than the basic range (8-9). Maximum adsorption $(44 \%)$ was observed at $\mathrm{pH} 5$ and minimum at neutral $\mathrm{pH}$ (Figure 8).

\section{Adsorption isotherm}

The adsorption isotherm is a graphical representation of the adsorbed dose of adsorbate against the residual concentration of adsorbate in the solution ${ }^{35}$. It is clear from the isotherm, when all active sites of biosorbent were occupied by dye molecules then no more adsorption occur; this indicates saturation biosorbent ${ }^{36}$. In the present study, analysis of adsorption isotherms (Freundlich and Langmuir models) revealed that the Freundlich isotherm model was more suitable for describing the adsorption of test dye (Orange-G) effluent by powdered biomass of C. vulgaris at all the parameters studied. Also, much better correlation coefficients were obtained using Freundlich equation when compared with Langmuir equation (Table $2)$. The Fruendlich model assumes existence of multilayered structure ${ }^{37}$ and also heterogeneous energetic distribution in the present case. It was suggested by Freundlich that the ratio of the adsorbed dose of adsorbate and the dose of adsorbate in the solution is not constant at different concentrations of solution ${ }^{35,38}$. However, Giles et $a l .{ }^{39}$ found that the Congo Red adsorption isotherm follows the Langmuir model. Hernández-Zamora et $a l .{ }^{36}$ reported a higher binding affinity of $C$. vulgaris towards Congo Red dye, and also lack of strong competition between the dye molecules and solvent to occupy the binding sites of the adsorbent.

\section{Characterization of the adsorbent material}

The characterization of algal biomass (C. vulgaris) was performed through physico-chemical methods as well as by infrared spectroscopy (FTIR) and scanning electron 


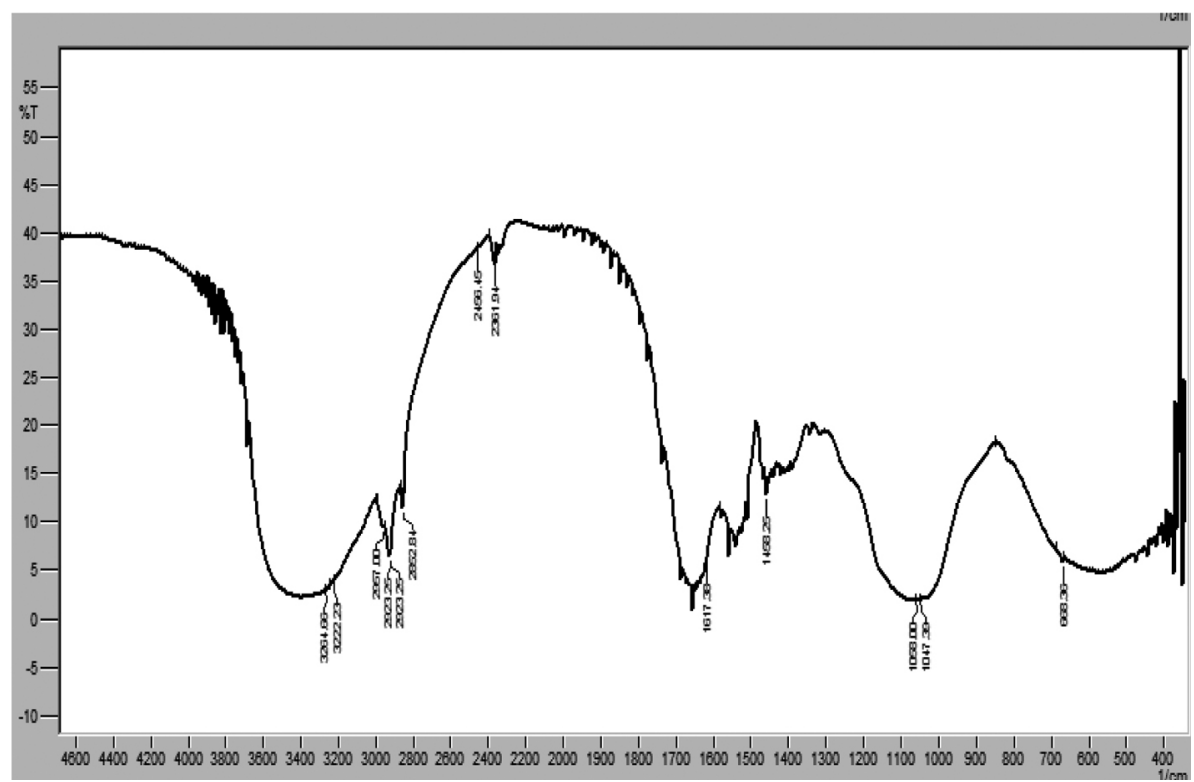

Figure 11. FTIR spectra of C. vulgaris biomass loaded with Orange-G dye.

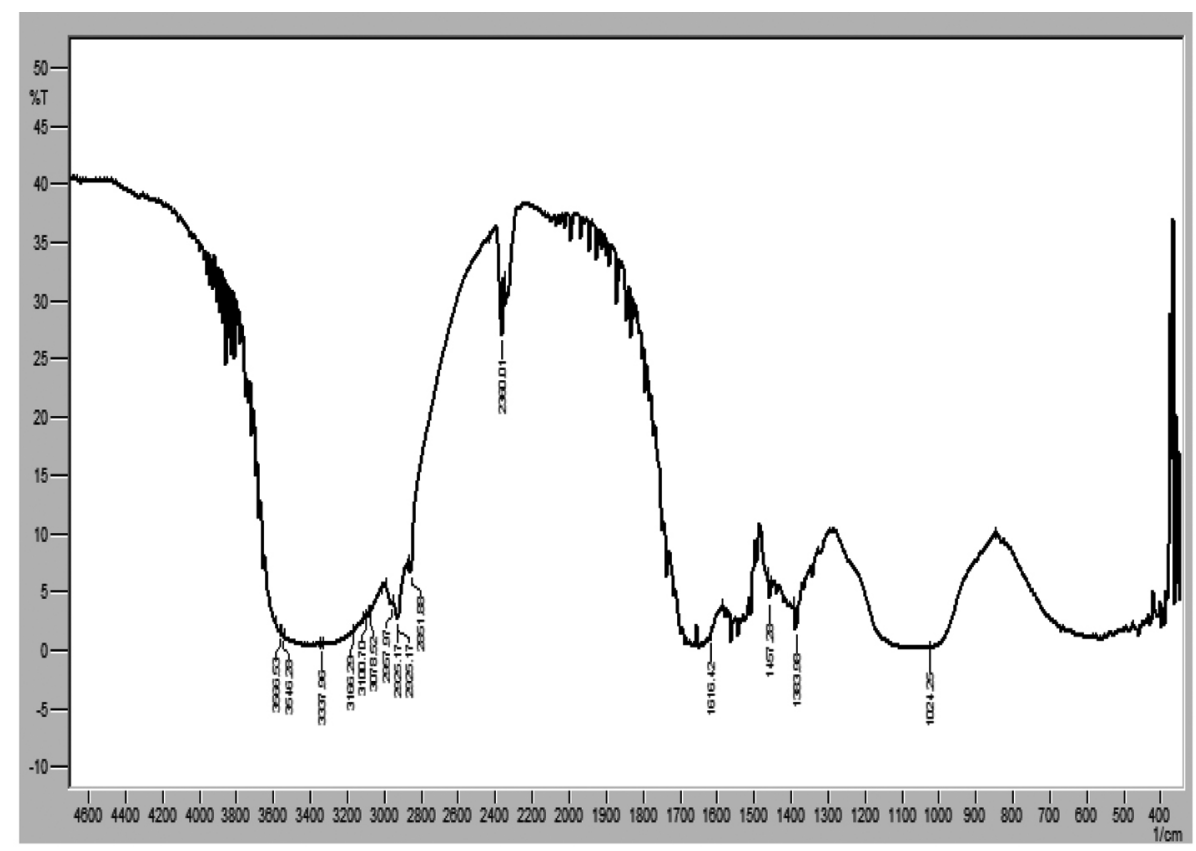

Figure 12. FTIR spectra of Chlorella vulgaris biomass (unloaded).

microscopy. Surface of the adsorbent was characterized before and after the decolourization reaction. The process of adsorption is associated with surface of the adsorbate. The intensity and rate of adsorption highly depend on that section of the adsorptive surface area which is available for adsorption. The dose of test dye (adsorbate) per unit weight of powdered biomass of test alga (adsorbent) is associated with size and shape of the particle, texture and composition. SEM image of unloaded particles of algal biomass (Figure 9) distinctly reveals that the surface of algal particles is mainly of irregular and porous form. As shown in Figure 10, pores in the loaded algal biomass particles are densely packed in comparison to unloaded biomass due to the presence of dye molecules.

\section{Infrared spectroscopic analysis}

The functional groups present on the surface of the adsorbent (algal biomass) were examined to identify those groups which are involved in the adsorption of the dye. Vibrational and rotational movements of different chemical bands and molecular groups present on the surface of the adsorbent are responcible for the adsorption process 
in the IR region. Spectral analysis from FTIR of the dyeloaded biomass of $C$. vulgaris showed a total of 13 peaks (Figure 11) in comparison to 15 peaks (Figure 12) shown by the unloaded biomass. The dye-treated algal biomass powder showed six new peaks while seven peaks shifted a little, but this shifting did not affect their respective functional groups. Eight peaks at wavenumbers 1024.25, 1383.98, 3078.52, 3100.70, 3166.29, 3377.96, 3546.28 and $3566.53 \mathrm{~cm}^{-1}$ respectively, disappeared from the spectrum after loading of dye molecules. This could be attributed to the presence of five strong functional groups, viz. $\mathrm{C}=\mathrm{S}$, aromatic rings, aromatic $\mathrm{C}-\mathrm{H}, \mathrm{CH}=\mathrm{CH}$, $=\mathrm{CH}_{2}$, and nine moderate groups such as aliphatic chains, amide and amine. FTIR studies demonstrated that strong groups, specially aromatic $\mathrm{C}-\mathrm{H}$ and $=\mathrm{CH}_{2}$, are incorporated in the mechanism of decolourization of Orange-G dye. The stress developed by the binding of dye molecules with algal biomass shifted the absorption peaks and also exposed some new strong functional groups $(\mathrm{C}-\mathrm{Br}$, $\mathrm{C}-\mathrm{Cl}, \mathrm{C}=\mathrm{S}$, aromatic rings). These new functional groups might play a role in multilayered model of adsorption mechanism and may be responsible for dye-binding 9,40 . Different types of adsorbents have been tested for removal of colourants from wastewater, including C. vulgaris ${ }^{41}$, blue-green algae and members of other algal groups. Different types of functional groups like sulphate, hydroxyl, carboxyl, phosphate and amine, including many other charged groups are present on the algal biomass, and act in the sequestration of pollutants ${ }^{42}$. Duygu et al. ${ }^{43}$ observed typical inorganic functional group of $C$. vulgaris and defined a series of chemical groups which are vibrationally active, including cellulose $(-\mathrm{C}=\mathrm{O})$, residual water $(-\mathrm{OH})$, protein (amide), lipid $\left(-\mathrm{CH}_{2}\right)$, starch $(-\mathrm{C}-\mathrm{O})$ and nucleic acid $(>\mathrm{P}=\mathrm{O})$.

\section{Conclusion}

Bio-removal is a sustainable approach towards the purification of coloured wastewater from different industrial processes. Result of the present study clearly indicate that the powdered biomass of $C$. vulgaris is an effective adsorbent for the removal of Orange-G dye from its aquatic solution. Adsorption profile of the algal species revealed that $50 \mathrm{mg} / \mathrm{ml}$ biomass dosage showed maximum biosorption. Optimum time, temperature and $\mathrm{pH}$ were found to be $10 \mathrm{~min}, 10^{\circ} \mathrm{C}$ and 5 respectively. Freundlich isotherm was found suitable to describe the results of adsorption experiments at equilibrium. SEM photomicrographs showed the biomass loaded with tested dye. FTIR studies confirmed the involvement of five strong binding groups and nine moderate groups. Two strong groups were found to be closely related with the bio-removal of Orange-G dye from effluents.

1. Ramachandra, T. V., Rajasekaramurthy, C. and Ahalya, N., Restoration of Lakes and Wetlands, Allied Publishers, India, 2002, p. 426.
2. Singh, U. B., Ahluwalia, A. S., Jindal, R. and Sharma, C., Water quality assessment of some fresh water bodies supporting vegetation in and around Chandigarh (India), using multivariate statistical methods. Water Qual. Exp. Health, 2013, 5, 149-161.

3. Mohan, S. V., Rao, C. N., Prasad, K. K. and Karthikeyan, J., Treatment of simulated Reactive Yellow 22 (azo) dye effluents using Spirogyra species. Waste Manage., 2002, 22, 575-582.

4. Dotto, G. L., Lima, E. C. and Pinto, L. A., Biosorption of food dyes onto Spirulina pletensis nanoparticles: equilibrium isotherm and thermodynamic analysis. Bioresour. Technol., 2012, 103, 123-130.

5. Fu, Y. and Viraraghavan, T., Dye biosorption sites in Aspergillus niger. Bioresour. Technol., 2002, 82, 139-145.

6. Radha, K. V., Regupathi, I., Arunagiri, A. and Murugesan, T., Decolorization studies of synthetic dyes using Phanerochaete chrysosporium and their kinetics. Process Biochem., 2005, 40, 3337-3345.

7. Bayramoglu, G., Celik, M. and Arica, Y., Biosorption of reactive blue 4 dye by native and treated fungus Phanerocheate chrysosporium: batch and continuous flow system studies. J. Hazard. Mater., 2006, 137, 1689-1697.

8. Horník, M., Suňovská, A., Partelová, D., Pipiška, M. and Augustín, J., Continuous sorption of synthetic dyes on dried biomass of microalga Chlorella pyrenoidosa. Chem. Pap., 2013, 67, 254-264.

9. Aksu, Z., Application of biosorption for the removal of organic pollutants: a review. Process Biochem., 2005, 40, 997-1026.

10. Goncalves, I. M. C., Gomes, A., Brás, R., Ferra, M. I. A., Amorim, M. T. P. and Porter, R. S., Biological treatment of effluent containing textile dyes. J. Color Technol., 2000, 116, 393-397.

11. Saravanan, N., Kannadasan, T., Basha, C. H. and Manivasagan, V., Biosorption of textile dye using immobilized bacterial (Pseudomonas aeruginosa) and fungal (Phanerochate chrysosporium) cells. Am. J. Environ. Sci., 2013, 9, 377-387.

12. Natali, F. C., Limaa, E. C., Royer, B., Bach, M. V., Dotto, G. L., Pinto, L. A. A. and Calvete, T., Comparison of Spirulina platensis microalgae and commercial activated carbon as adsorbents for the removal of Reactive Red 120 dye from aqueous effluents. $J$. Hazard. Mater., 2012, 241-242, 146-153.

13. Brookstein, D. S., Factors associated with textile pattern dermatitis caused by contact allergy to dyes, finishes, foams, and preservatives. Dermatol. Clin., 2009, 27, 309-322.

14. Alves de Lima, R. O., Bazo, A. P., Salvadori, D. M., Rech, C. M., de Palma Oliveira, D. and de AragãoUmbuzeiro, G., Mutagenic and carcinogenic potential of a textile azo dye processing plant effluent that impacts a drinking water source. Mutat. Res., 2007, 626, 53-60.

15. Carneiro, P. A., Umbuzeiro, G. A., Oliveira, D. P. and Zanoni, M. V. B., Assessment of water contamination caused by a mutagenic textile effluent/dye house effluent bearing disperse dyes. $J$. Hazard. Mater., 2010, 174, 694-699.

16. Slokar, Y. M. and Majcen Le Marechal. A., Methods of decoloration of textile wastewaters. Dyes Pigm., 1998, 37, 335-356.

17. Rathinam, A., Maharshi, B., Janardhanan, S. K., Jonnalagadda, R. R. and Nair, B. U., Biosorption of cadmium metal ion from simulated wastewaters using Hypnea valentiae biomass: a kinetic and thermodynamic study. Bioresour. Technol., 2010, 101, 1466-1470.

18. Renuka, N., Sood, A., Ratha, S. K., Prasanna, R. and Ahluwalia, A. S., Evaluation of microalgal consortia for treatment of primary treated sewage effluent and biomass production. J. Appl. Phycol., 2013, 25, 1529-1537.

19. Renuka, N., Sood, A., Prasanna, R. and Ahluwalia, A. S., Phycoremediation of wastewaters: a synergistic approach using microalgae for bioremediation and biomass generation. Int. J. Environ. Sci. Technol., 2015, 12, 1443-1460.

20. Singh, U. B. and Ahluwalia, A. S., Algae: indespensible for sustainability of life. In Science Technology and Environment: 
Perspective and Trends (eds Ahluwalia, A. S. and Gaur, R.), Panjab University, Chandigarh, 2014, pp. 45-50.

21. Mehta, S. K. and Gaur, J. P., Use of algae for removing heavy metal ions from wastewater: progress and prospects. Crit. Rev. Biotechnol., 2005, 25, 113-152.

22. Srinivasan, S. and Viraraghavan, T., Decolorization of dye wastewaters by biosorbents: a review. J. Environ. Manage., 2010, 190, 1915-1929.

23. Sood, A., Renuka, N., Prasanna, R. and Ahluwalia, A. S., Cyanobacteria as potential options for wastewater treatment. In Phytoremediation (eds Ansari, A. L. et al.), Springer, Cham, Switzerland, 2015, pp. 83-93.

24. Philipose, M. T., Chlorococcales, Indian Council of Agricultural Research, New Delhi, 1967, p. 365.

25. Rippka, R., Deruelles, J., Waterbury, J. B., Herdman, M. and Stanier, R. Y., Generic assignments, strain histories and properties of pure culture of cyanobacteria. J. Gen. Microbiol., 1979, 111, 1-61.

26. Freundlich, H., Adsorption in solution. Z. Phys. Chem. Soc., 1906, 57, 384-470.

27. Langmuir, I., The adsorption of gases on plane surfaces of glass, mica, and platinum. J. Am. Chem. Soc., 1918, 40, 1361-1368.

28. Nilsson, R., Nordlinder, R., Wass, U., Meding, B. and Belin, L. Asthma, rhinitis, and dermatitis in workers exposed to reactive dyes. Br. J. Ind. Med., 1993, 50, 65-70.

29. Vandevivere, P. C., Bianchi, R. and Verstratete, W., Treatment and reuse of waste water from the textile wet-processing industry: review of emerging technologies. J. Chem. Technol. Biotechnol., 1998, 72, 289-302.

30. Mantzavinos, D. and Psillakis, E., Enhancement of biodegradability of industrial wastewaters by chemical oxidation pretreatment. J. Chem. Technol. Biotechnol., 2004, 79, 431-454.

31. Singh, U. B. and Ahluwalia, A. S., Microalgae: a promising tool for carbon sequestration. Mitig. Adapt. Strat. Global Change, 2013, 18, 73-95.

32. Lim, S.-L., Chu, W.-L. and Phang, S.-M., Use of Chlorella vulgaris for bioremediation of textile wastewater. Bioresour. Technol., 2010, 101, 7314-7322.

33. Phang, S. M., Miah, M. S., Yeoh, B. G. and Hashim, M. A., Spirulina cultivation in digested sago starch factory wastewater. J. Appl. Phycol., 2000, 12, 395-400.

34. Phang, S. M., Chui, Y. Y., Kumaran, G., Jeyaratnam, S. and Hashim, M. A., High rate algal ponds for treatment of wastewater: a case study for the rubber industry. In Photosynthetic Microorganisms in Environmental Biotechnology (eds Kojima, H. and Lee, Y. K.), Springer Verlag, Hong Kong, 2001, pp. 51-76.
35. Shelke, R., Bharad, J., Madje, B. and Ubale, M., Adsorption of acid dyes from aqueous solution onto the surface of acid activated Nirgudi leaf powder (AANLP): a case study Int. J. Chem. Tech. Res., 2010, 2, 2046-2051.

36. Hernández-Zamora, M., Cristiani-Urbina, E., Martínez-Jerónimo, F., Perales-Vela, H. V., Ponce-Noyola, T., Montes-Horcasitas Mdel, C. and Cañizares-Villanueva, R. O., Bioremoval of the azo dye Congo Red by the microalga Chlorella vulgaris. Environ. Sci. Pollut. Res., 2015, 22, 10811-10823.

37. Fourest, E. and Volesky, B., Contribution of sulfonate groups and alginate to heavy metal biosorption by the dry biomass of Sargassum fluitans. Environ. Sci. Technol., 1995, 30, 277-282.

38. Velmurugan, P., Kumar, V. R. and Dhinakaran, G., Dye removal from aqueous solution using low cost adsorbent. Int. J. Environ. Sci., 2011, 1, 1492-1503.

39. Giles, C. H., Smith, D. and Huitson, A., A general treatment and classification of the solute adsorption isotherms. I: theoretical. J. Colloid Interface Sci., 1974, 47, 755-765.

40. Silverstein, P. M., Bassler, G. C. and Morrill, T. C., Spectrometric Identification of Organic Compounds, John Wiley, New York, 1991, 5th edn.

41. Aksu, Z. and Tezer, S., Biosorption of reactive dyes on the green alga Chlorella vulgaris. Process Biochem., 2005, 40, 1347-1361.

42. Seker, A., Shahwan, T., Eroğlu, A. E., Yilmaz, S., Demirel, Z. and Dalay, M., Equilibrium, thermodynamic and kinetic studies for the biosorption of aqueous lead(II), cadmium(II) and nickel (II) ions on Spirulina platensis. J. Hazard. Mater., 2008, 154, 973-980.

43. Duygu, D. Y., Udoh, A. U., Ozer, T. B., Akbulut, A., Erkaya, I. A., Yildiz, K. and Guler, D., Fourier transform infrared (FTIR) spectroscopy for identification of Chlorella vulgaris Beijerinck 1890 and Scenedesmus obliquus (Turpin) Kützing 1833. Afr. J. Biotechnol., 2012, 11, 3817-3824.

ACKNOWLEDGEMENTS. We thank the Chairpersons, Department of Botany, Panjab University, Chandigarh and Department of Botany, Choudhary Charan Singh University, Meerut for providing infrastructural and analytical facilities; UGC, New Delhi for financial support through BSR fellowship to S.K. and PURSE scheme, DST, New Delhi to the Department of Botany, Panjab University, Chandigarh.

Received 14 September 2017; revised accepted 14 June 2018

doi: $10.18520 / \mathrm{cs} / \mathrm{v} 116 / \mathrm{i} 4 / 604-611$ 